
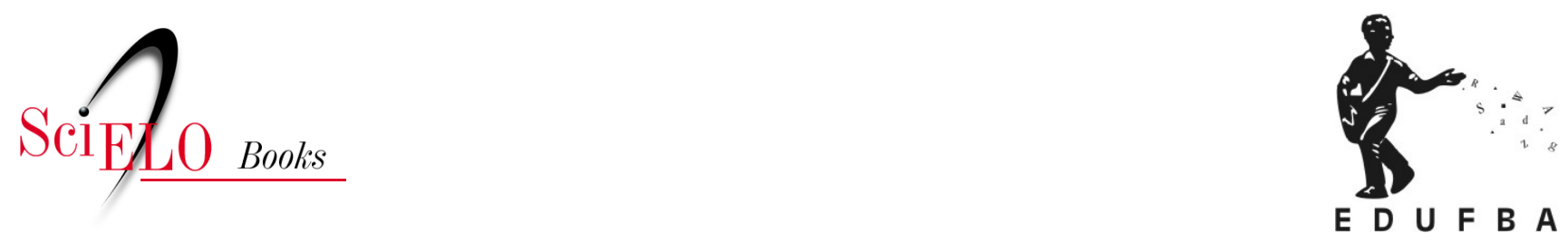

\title{
Pensar por atlas
}

\author{
Ricardo Trevisan
}

TREVISAN, R. Pensar por atlas. In: JACQUES, P.B., and PEREIRA, M.S., comps. Nebulosas do pensamento urbanístico: tomo I-modos de pensar [online]. Salvador: EDUFBA, 2018, pp. 46-69. ISBN 978-85-232-2032-7. https://doi.org/10.7476/9788523220327.0003.

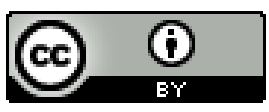

All the contents of this work, except where otherwise noted, is licensed under a Creative Commons Attribution 4.0 International license.

Todo o conteúdo deste trabalho, exceto quando houver ressalva, é publicado sob a licença Creative Commons Atribição 4.0.

Todo el contenido de esta obra, excepto donde se indique lo contrario, está bajo licencia de la licencia Creative Commons Reconocimento 4.0. 
PENSA R PO R 


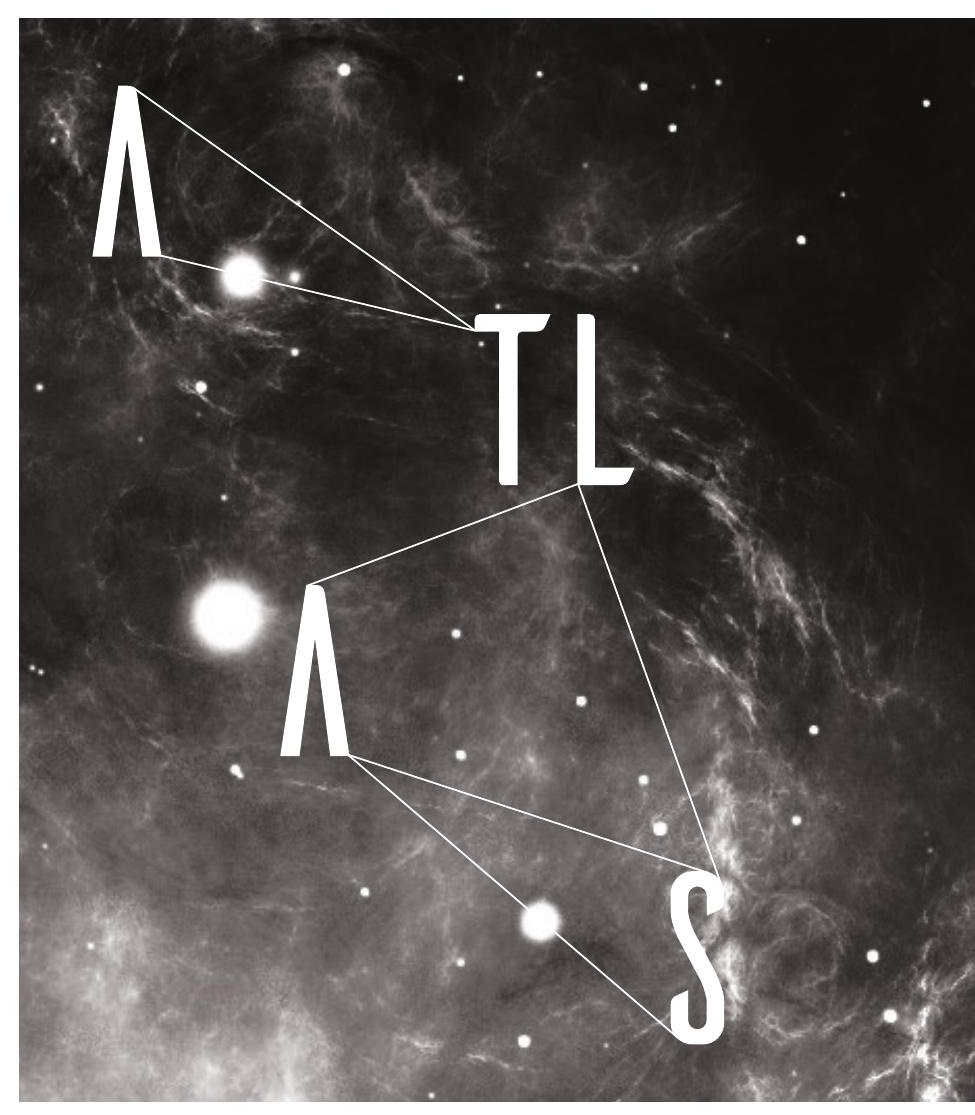




$$
\begin{aligned}
& P E N S \wedge \text { R } \\
& \text { P } 0 \text { R } \\
& \Lambda T L \Lambda S \\
& \text { 月 I C } A \text { 月 } 0 \\
& T \text { T E V IS } A N
\end{aligned}
$$


De vez em quando chego a vislumbrar uma Verdade mais verdadeira, escondida por trás de simulacros imperfeitos de si própria, mas, à medida que me aproximo, ela se move, mergulhando mais fundo no pântano agreste da cizânia. (MITCHELL, 2016)

uando o músico japonês Toshi Ichiyanagi compôs a obra "Cloud Atlas I-X" para piano, entre 1985 e 1999, ele sequer imaginou os desdobramentos de tal feito. Não tanto pela música - para desapontamento do compositor -, mas sim pelo título empregado. Ao atrair a atenção do escritor David Mitchell, o romancista inglês oportunamente apropriou-se dele para intitular seu terceiro livro: Cloud Atlas (Atlas de Nuvens), lançado pela editora britânica Sceptre em 2004. Best-seller em diversos países, essa premiada obra eclipsou a fonte original do título ao ser mais reconhecida, seja por publicações em vários idiomas, seja pela adaptação ao cinema em 2012. Particularmente, comprei o livro pelo nome, no intuito de auxiliar-me na atual pesquisa sobre atlas, tentando dele extrair possíveis definições ou interpretações.

Spoilerismo à parte, Atlas de Nuvens articula seis narrativas, separadas no tempo - de 1849 a 2321 - e no espaço - Polinésia, São Francisco, Londres, Seul etc. -, interligadas por personagens que possuem um elemento em comum: um cometa como marca de nascença. Histórias 
retratadas em tempos distintos - passado, presente e futuro -, cada qual com sua particularidade. Obra conduzida até o momento ápice de cada uma das seis tramas, quando se utiliza da cronologia reversa para conclui-las. Extratos temporais e espaciais conectados por elementos comuns a todos eles: desde objetos que avançam de um episódio a outro, até as personagens, suas interações e suas memórias. Diferentes imagens, construídas em momentos isolados, alinhavados por um plano maior, por toda aquela gama de sentimentos intrínsecos a qualquer indivíduo. Um romance fictício que aponta para o futuro apocalíptico e pós-apocalíptico da humanidade. Um livro indicado para quem gosta do gênero, porém pouco elucidativo para o motivo que me levou a comprá-lo. Para além da descoberta de que o título é oriundo de uma composição japonesa, o romance serviu ou para me distrair momentaneamente ou para conseguir dele sorver algumas poucas passagens, a exemplo: "O que não daria eu agora para ter um mapa inalterável dessa inefável constante? Possuir, por assim dizer, um atlas de nuvens?". (MITCHELL, 2016)

Fato é que nem Mitchell nem Ichiyanagi revelam os reais motivos que levaram à adoção do nome Cloud Atlas, fazendo-me lançar algumas especulações: seria pela efemeridade e inconstância inerentes à forma das nuvens? Seria pelo entendimento do atlas como um objeto que reflita o passar do tempo, o movimento, a transposição de algo? Ou seria pelas particularidades que cada imagem nos traz, criando a cada composição, a cada sobreposição de tempos distintos, uma narrativa reveladora? Nesse romance, as nuvens podem ser as diferentes histórias e narrativas, recortadas e agrupadas conforme o olhar do espectador. Enfim, explorações vagas que apenas ampliaram a "Verdade" sobre atlas, sem desanuviar qualquer possibilidade de conceituação.

De certo, não nos interessa meramente compreender o que é um atlas, como se ele fosse somente o quê, e não também o como. Almeja-se sim, com o presente estudo, transpor tais valores convencionais, atribuindo ao atlas um outro papel, uma qualificação que o retire de sua posição estática - objeto-produto - e o coloque em ação - dispositivo-motriz. Nesse sentido, o atlas deixa de ser uma obra física, com capa, folhas, ilustrações e textos elucidativos, e ganha imaterialidade, 50 transformando-se em meio, em método, em um modo de pensar por. 
Um ensaio que, ao discorrer sobre as possibilidades de utilizar o atlas como um método analítico da história, pretende compartilhar com pesquisadores e estudiosos interessados uma alternativa para nos debruçarmos sobre nossos familiares objetos e deles extrairmos interpretações e associações imprevistas ou inusitadas. Um saber construído a partir de experiência própria, a qual prometo não tratar como um registro narcísico, mas como uma dialética pela qual pretende-se suscitar elementos-chave à compreensão e ampliação de debate sobre o tema.

\section{Atlas em PRimeira pessoa}

Preciso deixar claro que o entendimento de "pensar por atlas" passa necessariamente por uma cronologia pessoal. Uma cronologia em primeira pessoa, pela qual a linha da minha história cruza com a linha das cidades novas, destacando-se dessa conexão os flertes, as fricções, os embates, as aquietações próprias a uma trama histórica. História iniciada em 1997, quando graduando no Instituto de Arquitetura e Urbanismo da Universidade de São Paulo, ao produzir o relatório de iniciação científica intitulado "Cidades Novas de colonização e expansão territorial no Noroeste do estado de São Paulo (1930-64)”, sob as orientações de Sarah Feldman e Carlos Roberto Monteiro de Andrade. História avolumada com estudos no mestrado ${ }^{1}$ e no doutorado $^{2}$, até chegar à atual pesquisa: Atlas de Cidades Novas no Brasil republicano, desenvolvida junto ao Laboratório de Estudos da Urbe (Labeurbe) da Faculdade de Arquitetura e Urbanismo da Universidade de Brasília (FAU-UnB).

Elaborado em 2011, o projeto de pesquisa foi um retorno à ideia lançada nas considerações finais da tese de doutorado Cidades Novas, de Trevisan (2009), com intuito de mapear casos brasileiros nos últimos 120 anos - investigação que me permitiria avançar nos estudos direcionados a esta, que considero uma tipologia urbanística. Um propósito claro para prosseguir e aplicar o conhecimento obtido, mas ainda obscuro no percurso para atingi-lo.

Inicialmente, o plano era identificar e reunir exemplares produzidos após 1889 no país, objetivando levantar, sistematizar e catalogar o 
maior número de informações relativas a cada um (dados biográficos) e revelar projetos urbanísticos empregados, associando-os às teorias em voga no período fulcral. Até o presente momento, tem-se contabilizadas mais de 260 cidades novas, disseminadas pelo território nacional nas mais diversas unidades federativas e implantadas a partir de 1892, com Aquidauana, no Mato Grosso do Sul, e Guarujá, em São Paulo. Destes e de outros exemplares que possam vir a ser descobertos, direcionarei a pesquisa, num primeiro estágio, para uma breve avaliação caso a caso, no intuito de montar uma ficha cadastral com os dados biográficos e iconográficos de cada cidade nova, bem como tratar os respectivos planos urbanísticos em escala similar, buscando facilitar análises morfológicas comparativas. De antemão, já se previa que seria um trabalho hercúleo, demandando dedicação plena e participação de outros pesquisadores (docentes e discentes). Porém, alguns procedimentos continuaram em aberto, como a análise dos produtos obtidos e o meio de divulgação dos dados confeccionados.

Definições que começaram a ser delineadas em 2015, quando me encontrei com a professora Paola Berenstein Jacques, da Faculdade de Arquitetura da Universidade Federal da Bahia (Faufba), durante estágio pós-doutoral em Nova York. Na ocasião, os primeiros passos de uma aproximação entre o Atlas de Cidades Novas e a Cronologia do Pensamento Urbanistico ${ }^{5}$ foram dados. Honrado pela proposta-convite de Berenstein em participar de tal projeto, com as boas-vindas da professora Margareth da Silva Pereira, da Universidade Federal do Rio de Janeiro (UFRJ), em outubro de 2015, a parceria foi efetivada em abril de 2016, quando ambas as pesquisadoras nos prestigiaram com a apresentação "Cronologia do Pensamento Urbanístico e o Pensar por Nebulosas” na IV Jornadas Labeurbeanas da FAU-UnB. A possibilidade de contribuir com dados obtidos pelo projeto Atlas de Cidades Novas e tê-los divulgados em renomada plataforma era, talvez, a peça que faltava à pesquisa. Caberia, nesse momento, dar sequência aos afazeres, articulando para cada cidade nova uma ficha cadastral e sua transposição ao modelo de verbetes da Cronologia.

Então, para cada cidade nova, um novo verbete. Assim, 260 cidades novas gerarão 260 verbetes a serem carregados na internet e dispo52 nibilizados à comunidade. Todavia, quando os verbetes começaram 
a ser elaborados, a necessidade de estabelecer arranjos, conexões, constelações e nebulosas trouxe-nos um dilema. Desde que o projeto Atlas foi concebido, a ideia era disponibilizar seus resultados numa homepage própria. Contudo, com a disponibilidade do site da Cronologia, questões operacionais surgiram: o que é um atlas e quais são as suas atribuições? Qual a real necessidade de se criar uma outra plataforma? Seria uma sobreposição de trabalhos? Ao criar uma página na web para o Atlas de Cidades Novas no Brasil republicano, estaria eu declinando da parceria, colocando em xeque o trabalho conjunto com as professoras Paola Berenstein e Margareth Pereira?

\section{Cronos ou Atlas? Mnemosyne responde!}

O presente manipula o passado virtual em seu próprio interesse, para dar crédito a suas mitologias e legitimidade à imposição da sua vontade. (MITCHELL, 2016)

Priorizar a Cronologia ou investir no Atlas? No afã de responder a esse dilema empírico, a esse jogo de polaridades - dinamografia ,$-{ }^{6}$ recorri aos deuses do Olimpo. Na mitologia grega, Cronos é o rei dos titãs e deus do tempo, aquele que regula e rege o destino de todos nós, enquanto Atlas é o titã que a tudo suporta, possuidor de conhecimento e sabedoria exasperantes. ${ }^{7}$ Portanto, cada qual com sua identidade, cada qual com seus predicados. Desse modo, espelhei tal delimitação para os projetos da Cronologia e do Atlas, os quais teriam distintamente função e atribuições claras e determinadas para com a pesquisa de cidades novas.

Mas se a Cronologia já apresenta uma maturação, um domínio maior por parte de seus autores e colaboradores, o mesmo não se tem do Atlas. Diante desse cenário, fez-se necessário compreender o atlas, entender sua origem, suas atribuições, seus significados, sua aplicação para essa pesquisa. Foi quando a deusa da memória, a Mnemosyne, apareceu para revelar um universo até então inexplorado. Em um primeiro contato com obra Memory, Metaphor, and Aby Warburg's Atlas of Images, de Christopher D. Johnson (2012), fui apresentado ao Atlas Mnemosyne, ou Bilderatlas, ou Atlas de Imagens, de autoria 
do filósofo e historiador alemão Abraham Moritz Warburg (18661929), notoriamente Aby Warburg, elaborado entre 1927 e 1929. Obra-prima, inacabada, o atlas warburguiano é considerado seu testamento metodológico, pois possibilita repensar o modus operandi de trabalhar e ler a história.

Esse novo percurso desviou-me do anterior, daquele de compreender um atlas aos moldes do gênero epistêmico produzido desde o Renascimento, quando Gerardus Mercator (1512-1594), no século XVI, usava a figura simbólica do titã como a capa de seus livros de mapas. (ENCYCLOPÆDIA BRITANNICA, 1985) Essa coletânea de imagens, gráficos, ensaios e ilustrações tornou-se recorrente durante o enciclopedismo das Luzes, reunindo informações de um determinado assunto - fronteiras, clima, mares e rios, economia, geologia, população etc. - a partir de diferentes panoramas, do particular ao genérico, do local ao global, ou vice-versa. Um gênero ilustrativo e instrutivo, uma "forma visual de conhecimento", geralmente de agradável leitura, "[...] cujo propósito é oferecer aos nossos olhos, de modo sistemático ou problemático - incluindo o poético com risco a erros $[\ldots]-$, toda uma multiplicidade de coisas ali reunidas por afinidades eletivas". (MUSEU NACIONAL CENTRO DE ARTE REINA SOFÍA, 2010) Um gênero científico que ganhou espaço em diversas áreas, como nas ciências da vida e seus infindáveis atlas de medicina, e até mesmo na disciplina do Urbanismo, como revelam algumas produções.

O antológico Atlante di Storia dell'Urbanistica: dalla preistoria all'inizio del secolo XX (1963), de Mario Morini, contempla planos urbanísticos, edifícios emblemáticos e personagens de destaque na produção do espaço urbano, desde o Egito Antigo até as teorias de Howard e Tony Garnier. Um retrato pela história da humanidade, associando-a à história das cidades e de suas culturas. Um documento iconográfico e consultivo, como o próprio autor descreve em seu prefácio, com enfoque na essência do processo urbanístico e dos valores espaciais presentes em diferentes épocas. Um resgate histórico que evidenciou, ao momento de sua publicação, o fervoroso debate sobre intervenções conscientes em centros consolidados, contrapondo-se à tábula rasa e 54 ao pragmatismo modernista. Um atlas como manifesto urbanístico. 
As recentes e curiosas obras Atlas of lost cities: a travel guide to Abandoned and Forsaken Destinations (2014), do francês Aude de Tocqueville, e Atlas of improbable places: a journey to the world's most unusual corners (2016), dos ingleses Travis Elborough e Alan Horsfield, trazem localidades não habituais do senso comum, revelando no diferente, no esquecido, um campo rico a ser explorado. Na primeira, diagramada como um mapa de caça ao tesouro, temos assentamentos abandonados ou cidades fantasmas na África, América, Ásia e Europa, representadas por gravuras esquemáticas e textos que trazem a história de cada exemplar, de seu nascimento a sua morte. Já a segunda retrata locais - ilhas, desertos, ruínas, palácios, monumentos, núcleos urbanos etc. - presentes nos quatro cantos de nosso planeta e que chamam a atenção por se destoarem da paisagem circundante. Como elo entre ambas, a referência ao célebre Le città invisibili (1972), de Italo Calvino. Dueto de atlas excêntrico, lúdico e divagante.

No pretencioso trabalho Atlas of Cities (2016), de Paul Knox, verificam-se quatro funções fundamentais nas cidades e estipulam-se 13 tipos de assentamentos, ${ }^{8}$ pelos quais o autor buscou retratar o universo urbano contemporâneo nos cinco continentes. Um seleto número de exemplares mapeados e tipificados por "padrões e processos de urbanização - atuais e passados” (KNOX, 2016, p. 11), conduzidos pelo olhar e direcionamento de pesquisadores locais. Um conteúdo auspicioso, porém restrito aos estudos de caso escolhidos. Para o mundo cada vez mais urbano, taxonomias definidoras e limitadoras são um tanto quanto incongruentes. Um atlas radiográfico parcial de nossas urbes.

Já a trilogia de atlas organizada por Rebecca Solnit e Jelly-Schapiro, aqui representada pelo Nonstop Metropolis: a New York City Atlas (2016), aborda três metrópoles norte-americanas - São Francisco, Nova Orleans e Nova York - a partir de experiências etnográficas e culturais, de mapas imagéticos e ensaios informativos; enfim, o lado $B$ das cidades que não se encontra em guias tradicionais de turismo ou aplicativos similares. Uma deriva por atrativos e espacialidades dedicada aos errantes dispostos a desvendar recantos eclipsados de tais cidades. Uma tríade atlante alternativa e instigante. 
A obra referencial Imagens de vilas e cidades do Brasil Colonial (2000), do professor Nestor Goulart Reis, mesmo sem “atlas” no título, é um catálogo iconográfico e cartográfico de amplitude sobre cidades, vilas, povoações e aldeias brasileiras dos séculos XVI ao XVIII. Um material organizado por critérios geográficos e seguindo uma ordem cronológica, referenciado por textos originais presentes nas gravuras e desenhos ou notas explicativas. Um trabalho direcionado ao grande público (exemplares no formato livro e CD-ROM), não apenas a especialistas em estudos das imagens. Uma coletânea construída desde a década de 1960, tendo um estudo prévio daquilo a ser divulgado, segundo o entendimento do autor e de seus colaboradores, realizando-se apenas "[...] o recolhimento dos desenhos que pudessem, direta ou indiretamente, servir para o conhecimento dos núcleos urbanos no seu conjunto”. (REIS, 2000, p. 12) Um atlas sobre a nossa ancestralidade urbana.

E, nessa mesma temática, tem-se a produção Atlas histórico da América Lusa (2016), dos professores e historiadores da UnB Tiago Gil e Leonardo Barleta. Uma coletânea riquíssima de informações sobre cidades, vilas, freguesias, povoados e até mesmo tabas indígenas existentes no território sul-americano quando sob o domínio português. Uma obra que transpassa a materialidade de seu exemplar físico e ganha consistência e alcance público em sua versão virtual. ${ }^{9}$ Um atlas histórico interativo, sinais dos novos tempos.

Todavia, identificou-se em tais exemplares a exceção da versão digital do Atlas da América Lusa, uma limitação no manuseio e no uso desses volumes. Embora confirmem, na essência, ser uma coletânea sobre um determinado tema, o modo estanque, imóvel, fixo com que seus objetos, suas imagens, seus dados são apresentados, seguindo uma organização dada a priori por cada autor, restringe a interatividade entre o usuário e a obra. $\mathrm{O}$ modus operandi é predeterminado, cabendo ao leitor pouca margem de manobra. $\mathrm{O}$ atlas adquire, portanto, os moldes daquilo que resolvi denominar de objeto-produto.

Já o Atlas Mnemosyne de Aby Warburg foge a essa regra, ao trazer não um atlas, um objeto-produto encerrado em si mesmo, mas um modo de pensar por. Um método em que o espectador é o sujeito que irá 56 conectar as relações existentes entre as imagens. Nesse sentido, o 
filósofo e historiador francês Georges Didi-Huberman foi essencial para melhor compreender o atlas warburguiano. E o ponto de partida foi assistir a sua entrevista enquanto curador da exposição ATLAS, ¿Cómo llevar el mundo as cuestas? (2010), realizada pelo Museu Nacional Centro de Arte Reina Sofía, em Madri.

Nessa entrevista, Didi-Huberman suscitou alguns preceitos que aproximam aquilo visionado para o Atlas de Cidades Novas. Em uma das passagens, afirma:

Atlas é uma forma de conhecimento visual. Atlas é uma apresentação sinóptica de diferenças: vê-se uma coisa e outra completamente distinta colocada ao seu lado. O atlas é uma ferramenta muito mais visual do que pode ser qualquer arquivo; é um trabalho de montagens em que se unem tempos distintos; é um choque. (MUSEU NACIONAL CENTRO DE ARTE REINA SOFÍA, 2010, tradução nossa)

Justamente, o atlas warburguiano traz em si a possibilidade de impactos e confrontações proporcionados por nexos entre imagens diferentes, não pela similaridade e nem pela coexistência em um mesmo tempo, mas por conexões obscuras até então inimagináveis e pela sobreposição de tempos distintos (heterocronia). Nesse sentido, a exposição realizada em Madri teve como propósito aproximar esse modo de associação - esse modo de pensar - a produções de artistas dos séculos XX e XXI, tendo a história da imaginação como enredo principal. Ao percorrer a exposição, não se tinha uma única narrativa, mas tantas quantas fossem possíveis de se estabelecer.

Portanto, distinto à concepção limitada que se tinha inicialmente, o atlas warburguiano sacudiu minha percepção sobre tal objeto, aproximando-o ao método de pensar por nebulosas debatido no projeto da Cronologia do Pensamento Urbanístico. ${ }^{10} \mathrm{O}$ atlas warburguiano objetiva possibilitar narrativas. Para além de um trabalho de síntese, o atlas é, antes de mais nada, um working process, um meio, um processo em constante realização feito sobre uma mesa, um suporte, em que arranjos, montagens e colocações são estabelecidos conforme os objetos disponibilizados. Como resultado, sempre leituras distintas. 
Assim, o atlas passou a ser encarado por mim não mais como um objeto-produto, mas como um meio, uma ferramenta, um modo de ver e compreender - um dispositivo-motriz.

Algo melhor depurado pela leitura de Atlas ou Gaia a ciência inquieta: o olho da história (2013), de Georges Didi-Huberman, um livro em que o filósofo irá esmiuçar e interpretar o trabalho de Aby Warburg à luz de outros pensadores, um conteúdo que permitiu romper com as ideias iniciais pretendidas para o projeto Atlas de Cidades Novas, visionando novas possibilidades e tendo mais claro os rumos a serem seguidos.

Ao buscar interpretar a obra inacabada de Aby Warburg, DidiHuberman nos contempla com algumas ponderações, definições e caracterizações, a partir das quais estabeleço com o autor um diálogo textual a fim de estruturar uma possível definição funcional para atlas.

A leitura e o uso de um atlas se dá por dois modos: ou objetivamente (ao se procurar uma informação precisa); ou erraticamente, por divagação, sem intenção (ao se deixar devanear por suas páginas).

[...] um atlas dificilmente se constitui por 'página' no sentido habitual do termo: será antes por tabelas, por pranchas, onde se encontram dispostas imagens, pranchas que consultamos com um fim específico ou que folheamos por prazer, deixando divagar, de imagem em imagem e de prancha em prancha, a nossa 'vontade de saber'. (DIDI-HUBERMAN, 2013, p. 11)

Nesse sentido, compara o atlas a uma mina explosiva composta pela soma entre a estética e o saber. O atlas é, ao mesmo tempo, uma "forma visual do saber" - paradigma estético - e uma "forma sábia do ver" - paradigma epistêmico -, embaraçando quaisquer limites de inteligibilidade. "Contra toda a pureza epistémica, o atlas introduz no saber a dimensão sensível, o diverso, o carácter lacunar de cada imagem. Contra toda a pureza estética, introduz o múltiplo, o diverso, a hibridez de toda a montagem”. (DIDI-HUBERMAN, 2013, p. 12)

E desse somatório entre a estética e o saber, o atlas surge como um 58 método sem limites, sem certezas preestabelecidas, como "[...] uma 
teoria do conhecimento exposta ao perigo do sensível e a uma estética exposta ao perigo da disparidade". (DIDI-HUBERMAN, 2013, p. 13)

Quebra as certezas autoproclamadas da ciência convicta das suas verdades, como da arte convicta dos seus critérios. Inventa, entre tudo isto, zonas intersticiais de exploração, intervalos heurísticos. Ignora deliberadamente os axiomas definitivos [...]. Desconstrói, pela sua própria exuberância, os ideais de unicidade, de especificidade, de pureza, de conhecimento integral. (DIDI-HUBERMAN, 2013, p. 12)

Atlas torna-se, assim, um instrumento, uma ferramenta de abertura às possibilidades ainda não experimentadas, cuja força-motriz é a imaginação. $\mathrm{O}$ atlas proporciona a obtenção do conhecimento pela imaginação. Imaginação presente no conhecimento transversal, no processo de montagem, desmontagem e remontagem. $\mathrm{O}$ atlas, portanto, não é um simples arquivo, mas uma ferramenta. "A imaginação aceita o múltiplo e renova-o sem cessar, a fim de aí detectar novas 'relações íntimas e secretas', novas 'correspondências e analogias', que serão por seu turno inesgotáveis [...]”. (DIDI-HUBERMAN, 2013, p. 14)

Uma ferramenta a se configurar como um suporte de encontros - como uma mesa, uma "Mesa de oferenda, mesa de cozinha, de dissecção ou de montagem”. (DIDI-HUBERMAN, 2013, p. 17)

A mesa mais não é do que o suporte de um trabalho que pode ser continuamente retomado, modificado, senão mesmo recomeçado. É apenas uma superfície de encontros e de disposições passageiras [...] seu plano de trabalho [...] acolhe sem hierarquia. (DIDI-HUBERMAN, 2013, p. 18)

Uma ferramenta anacrônica ao admitir e trabalhar tempos heterogêneos. Uma ferramenta potencializadora de se ver e ler o tempo. "É o tempo mesmo que se torna visível na montagem das imagens [pensamentos urbanísticos, práticas profissionais]. Compete a cada um converter tal visibilidade na potência de ver os tempos". (MUSEU NACIONAL CENTRO DE ARTE REINA SOFÍA, 2010) 
Uma ferramenta com regra própria: o "princípio-atlas”, o princípio da efemeridade, do provisório, do passageiro.

O atlas, por seu turno, não é guiado senão por princípios móveis e provisórios, aqueles que podem fazer surgir inesgotavelmente novas relações - muito mais numerosas do que os termos entre si - entre coisas ou palavras que, inicialmente, nada parecia emparelhar. (DIDI-HUBERMAN, 2013, p. 14)

Desse provisional, surgem dois caminhos de leituras possíveis: uma denotativa (em busca de mensagens) e outra conotativa (em busca de montagens - com destaque especial para essa). $\mathrm{O}$ atlas pode ser compreendido, em suma, não somente como uma ferramenta, mas como um aparelho de leitura, uma máquina do saber, um objeto de saber e contemplação.

Poderá considerar-se [...] que o atlas de imagens é uma máquina de leitura no muito amplo sentido que Benjamin pretendeu atribuir ao conceito de Lesbarkeit. [...] $\mathrm{O}$ atlas seria um aparelho da leitura antes de tudo, quero dizer, antes de qualquer leitura 'séria' ou 'em sentido escrito': um objeto de saber e de contemplação para as crianças, ao mesmo tempo infância da ciência e infância da arte. (DIDI-HUBERMAN, 2013, p. 15)

Portanto, o atlas warburguiano inventou uma maneira de dispor as imagens entre si e inaugurou um novo gênero do saber: a aposta um modo de reler o mundo por narrativas antes despercebidas ou inimagináveis.

A aposta de que as imagens, agrupadas de uma certa maneira, nos ofereceriam a possibilidade - ou melhor, o recurso inesgotável - de uma releitura do mundo. Reler o mundo: vincular de modo diferente os pedaços díspares, redistribuir a sua disseminação, um modo de a orientar e de a interpretar, é certo, mas também de a respeitar, de a remontar sem pretender resumi-la nem esgotá-la. (DIDI-HUBERMAN, 2013, p. 19-20) 
Um modo de reler o mundo, sobretudo, porque o atlas warburguiano tem um caráter permutável de configurar seus objetos, suas imagens "fecundidade heurística e desrazão". (DIDI-HUBERMAN, 2013, p. 20) Para Warburg, o pensamento é uma matéria de formas transformantes, e não de formas fixas.

Nem desordem absolutamente louca, nem ordenação muito sensata, o atlas Mnemósine delega na montagem a capacidade de produzir, através de encontros de imagens, um conhecimento dialético da cultura ocidental, essa tragédia sempre renovada - sem síntese, portanto - entre a razão e desrazão, ou, como dizia Warburg, entre os astra do que nos eleva até o céu do espírito e os monstra do que nos precipita até às profundezas do corpo. (DIDI-HUBERMAN, 2013, p. 21, grifo do autor)

Um modo de reler o mundo que influenciou as ciências humanas, verificado nas obras de compilação e de remontagem de vários artistas. ${ }^{11}$

O atlas, desde Warburg, não só modificou em profundidade as formas - portanto, os conteúdos - de todas as 'ciências da cultura' ou ciências humanas, como incitou ainda um grande número de artistas a representar por completo, em forma de compilação e de remontagem, as modalidades segundo as quais as artes visuais são hoje elaboradas e apresentadas. (DIDI-HUBERMAN, 2013, p. 17)

Esse modo de releitura está presente no atlas autobiográfico de Jorge Luis Borges e María Kodama, de 1984. Embora refute a ideia de atlas, o escritor argentino refere-se a ela como trama e caos intencionalmente compartilhados no mesmo objeto.

Acho que o primeiro a falar na pluralidade das causas foi Stuart Mill; no que se refere a este livro, que certamente não é um Atlas, posso apontar duas, inequívocas. A primeira se chama Alberto Girri. No grato decurso de nossa residência na terra, María Kodama e eu percorremos e saboreamos muitas regiões, que sugeriram muitas fotografias e muitos textos. Enrique Pezzoni, a segunda causa, viu-as; Girri observou que 
elas poderiam tramar-se num livro, sabiamente caótico. (BORGES, 2010, p. 9)

Em síntese, o atlas warburguiano é um objeto que se lê e se usa de modo objetivo ou errático, tensionado por paradigmas estético e empírico, cujos limites da compreensão nem sempre são claros. Um dispositivo movido pela imaginação, cuja base de suporte é uma mesa; um dispositivo concomitantemente negligente e potencializador do tempo; um dispositivo regrado pelo aleatório, pelo improviso. Um dispositivo de leitura de caráter permutável, com características de uma máquina do saber e de contemplação. Um jeito novo de relacionar imagens, uma maneira de reler o mundo.

Aby Warburg, ao reunir todos os objetos de sua pesquisa em uma ferramenta de "painéis móveis" constantemente montados, desmontados, remontados, deu ao atlas um novo sentido. O titã Atlas, portador do mundo em seus ombros, definitivamente daria significado a seus predicados - depositário de conhecimento e sabedoria - a partir do trabalho warburguiano e das interpretações elaboradas por Didi-Huberman.

Desse modo, ao rebater tais leituras na pesquisa de cidades novas, nosso Atlas seria o suporte às imagens, às cidades novas e seus atributos; enquanto a Cronologia seria a mesa onde as amálgamas seriam condensadas e expostas. No Atlas, visionaríamos cada objeto e seus predicados; na Cronologia, compreenderíamos suas relações e conexões "íntimas e secretas". No Atlas, teríamos as cartas; na Cronologia, jogaríamos o jogo, tal qual:

Baralhar e distribuir as cartas, desmontar e remontar a ordem das imagens numa mesa para criar configurações heurísticas 'quase adivinhas', ou seja, capazes de entrever o trabalho do tempo sobre o mundo visível: esta seria a sequência operatória de base para qualquer prática a que aqui chamamos atlas. (DIDI-HUBERMAN, 2013, p. 55)

O site Atlas de Cidades Novas representaria o grande arquivo de ob62 jetos, a primeira mesa, cabendo ao site da Cronologia reproduzir as 
"montagens", as nebulosas, confeccionadas a partir de diferentes leituras. E a cada montagem, a cada narrativa criada, teremos como resultado novos olhares e um aumento de conhecimento sobre a tipologia "cidades novas" e, consequentemente, sobre a história da cidade e do urbanismo no Brasil.

\section{As IMAGENS NO ATLAS, AS AMÁlgAMAS NA CRONOLOGIA}

O passado real é frágil, cada vez + apagado e + difícil de acessar e reconstruir: em contraste, o passado virtual é maleável, cada vez + nítido e + difícil de contornar/denunciar como uma fraude. (MITCHELL, 2016)

Ciente dos predicados de cada plataforma e da compreensão do atlas como um meio, e não um fim, cabe aqui expor a operacionalidade da pesquisa.

O Atlas de Cidades Novas, com o Brasil republicano como recorte temporal, será uma plataforma na web na qual estarão os dados básicos sobre cada exemplar de cidade nova encontrado, devidamente cadastrado e catalogado. Assim como Didi-Huberman (2010) referiu-se à obra warburguiana, será um trabalho de "história natural infinita", um "atlas do impossível", pelo qual se pretende recolher os casos de cidades novas originários no Brasil desde 1889. Como catadores de cidades novas e de seus atributos, daremos luz a informações não encontradas na historiografia urbana brasileira. Pretendemos criar condições para "reconfigurar a ordem dos lugares", em que não há um só modo de se contar a história das cidades novas no Brasil. Fazer um atlas é reconfigurar o espaço, redistribuí-lo, desorientá-lo. Montar um Atlas de Cidades Novas é possibilitar a releitura do urbanismo e da urbanização brasileira, a partir de, no mínimo, 260 exemplares já encontrados.

Ilustrativamente, o site consistirá na primeira aproximação ao tema e aos exemplares. A partir da página inicial, haverá acesso ao mapa do Brasil pontuado por cidades novas. Ao clicar em cada cidade, será aberta uma imagem: o mapa com as delimitações originais daquilo 
que foi o projeto da cidade nova em sua origem, sem considerar a expansão da mesma. A exemplo do estudo feito por Philippe Panerai e colaboradores (1985) sobre as bastides francesas, a intenção é ter uma compreensão sobre o traçado projetado de cada cidade nova. Para cada cidade, quando desejado, um quadro com os seis atributos - os seis genes - se abrirá, contendo informações básicas: empreendedor, função dominante, região, projetista, filiação teórica e data do projeto. Também constará nesse quadro um link para o verbete no site da Cronologia do Pensamento Urbanístico. O site Atlas ainda terá um dispositivo de filtro que permitirá ao interessado estabelecer as correspondências preliminares, seja por empreendedor, função dominante, região, profissional, projeto ou período; seja por combinações desses atributos. E como disse Cláudio de Moura Castro (1978, p. 312-313): "O levantamento de dados, de hoje ou de ontem, é apenas o princípio”.

Concomitantemente, os verbetes para o site da Cronologia, com informações mais detalhadas de cada cidade, serão elaborados e adicionados à respectiva plataforma, juntamente com arranjos preliminares já formulados.

Será na e para a Cronologia que teremos a liberdade para criar as amálgamas, modificá-las, remontá-las em pilhas, constelações e nebulosas. ${ }^{12}$ As variáveis, os atributos das cidades novas serão articulados a fim de descobrir novas analogias, novos trajetos de pensamentos, até mesmo percursos profissionais ofuscados. (PEREIRA, 2014) Não haverá uma única nebulosa de cidades novas, mas inúmeras. A depender da porta de entrada escolhida, tramam-se distintas urdiduras e tessituras, definem-se procedimentos e métodos específicos, revisitam-se e revisam-se certezas e narrativas conclusivas e encerradas. Seja pela função dominante original (administrativa, empresarial, balneária, colonizadora, de relocação, satélite, de expansão); pelas personagens envolvidas (empreendedores, planejadores, projetistas, construtores, habitantes); pelos atributos físicos assumidos (sítio, projetos urbano e arquitetônico, paisagem, zoneamento); pelo contexto histórico (aspectos político-econômico-sociais); cada investigação sobre cidades novas direciona seu lineamento e estabelece suas aproximações e, por 64 conseguinte, suas distinções. 
A partir dessa constelação, as mais distintas formas vaporosas podem ser captadas, registradas e decifradas. Atlas de Cidades Novas permitirá ao interessado montar, a critério ou aleatoriamente, a sua nebulosa. Assim, a construção e disponibilização de uma imagem abrangente de cidades novas, a partir de um resgate histórico de sua produção, permitirão compreender a dinâmica das transformações urbanas no país nos últimos 120 anos. Do mesmo modo, a construção de um arcabouço referencial para todo e qualquer estudo urbanístico e arquitetônico auxiliará pesquisadores a entender os fatores que contribuíram para os atuais cenários urbanos, bem como aumentará o repertório de profissionais, docentes e discentes debruçados sobre a temática.

O Atlas de Cidades Novas não será apenas uma narrativa dessas tipologias na cronologia de longa duração, mas o dispositivo que possibilitará atentar e criar tantas outras narrativas quantas forem possíveis - histórias que narrem a origem do projeto e a construção dessas cidades; histórias que permitam uma melhor compreensão do processo de urbanização e do urbanismo no século XX em nosso país. Um arranjo feito a partir de informações obtidas e contidas no Atlas de Cidades Novas, a ser disponibilizado na Cronologia do Pensamento Urbanístico. Por ora, a "Verdade mais verdadeira" por mim encontrada, até ela se entreverar novamente às profundezas da "cizânia". 


\section{NOTAS}

1 Dissertação Incorporação do ideário da Garden-City inglesa na urbanística moderna brasileira: águas de São Pedro, realizada entre 2001 e 2003 no Programa de Pós-Graduação em Engenharia Urbana da Universidade Federal de São Carlos (UFSCar), orientada por Ricardo Siloto da Silva. Um estudo de caso aprofundado sobre esse balneário paulista, uma cidade nova planejada pelo engenheiro civil Luiz Camerlingo (1908-1938) e projetada sob o comando rigoroso do engenheiro Jorge de Macedo Vieira (1894-1978) nos anos 1930. Uma cidade nova empreendida por empresários do café, envolta pela lógica do turismo e pela comercialização de lotes urbanizados. Um projeto cuja filiação teórica nos remete, em parte, aos preceitos howardianos de fins do século XIX.

2 Tese: Cidades Novas, desenvolvida entre 2006 e 2009 junto ao Programa de PósGraduação em Arquitetura e Urbanismo da UnB, sob a supervisão de Sylvia Ficher e com contribuições precisas de Philippe Panerai e Donatella Calabi durante estágio doutoral em Paris e Veneza. Nesse trabalho, cheguei a seis atributos verificados e aplicados em dezenas e dezenas de estudos de caso analisados - seis genes a comporem o DNA de uma cidade nova. Nesse sentido, identifico uma cidade nova como núcleos urbanos: 1) empreendidos pelo desejo do poder público e/ou da iniciativa privada e concretizado em ações específicas; 2) que buscam atender, ao menos de início, a uma ou mais funções dominantes (administrativa, de colonização, ferroviária, de relocação, balneária, satélite etc.); 3) implantados num sítio previamente escolhido; 4) a partir de um projeto urbanístico; 5) elaborado e/ou desenvolvido por agente(s) definido(s) - eventualmente profissional(is) habilitado(s); e 6) em um limite temporal determinado, implicando inclusive em um momento de fundação razoavelmente preciso.

3 Projeto de pesquisa apresentado ao Conselho Nacional de Desenvolvimento Científico e Tecnológico (CNPq) para obtenção de Bolsa de Produtividade (PQ2), contemplado para o triênio 2015-2018.

4 Paul Veyne irá abordar o emprego das palavras "teoria", "tipo" e "conceito" em seu livro Como se escreve a história (2014). Mesmo de acordo com a ideia de que "tipo" ou "teoria" "só podem servir para abreviar uma descrição", com ressalvas para "uma tipologia só estaria completa se a sua compreensão fosse muito fraca e se ela se reduzisse a um inventário do léxico histórico” (VEYNE, 2014, p. 100), eu intencionalmente utilizo a palavra "tipologia" para me referir a um caso - cidades novas - em que a repetição de esquemas - os seis atributos - se faz presente em inúmeros exemplares. Como Veyne (2014, p. 99) coloca, “[...] ao encontrar os mesmos fatos, há séculos e a milhares de léguas de distância, parece que ficou excluído qualquer acaso [...] pois adapta-se a uma misteriosa lógica das coisas”.

5 Para maiores detalhes, acessar: <http://www.cronologiadourbanismo.ufba.br/>. 
6 Aby Warburg denominou o jogo de polaridades como uma dinamografia, um "[...] jogo permanente, um pouco ofegante, poderia dizer-se, de polaridades sempre em movimento, sempre em conflito ou em transformações recíproca”. (DIDI-HUBERMAN, 2013, p. 77)

7 Como descreve Georges Didi-Huberman (2013, p. 76, grifo do autor), "A palavra atlas, em grego, é formada pela combinação do a prostético (ou seja, da adjunção, no início de uma palavra, de um elemento não etimológico que não modifica o sentido da própria palavra) e de uma forma do verbo tlaô, que significa 'portar', 'suportar'. Tlas ou atlas é, portanto, no sentido literal, o portante, o portador por excelência. Mas suportar não é, de todo, um gesto simples. Suportar só é possível graças ao encontro de dois vetores antagonistas, o peso por um lado, a força muscular por outro. Suportar manifesta, portanto, a potência do portador, mas igualmente o sofrimento a que está sujeito sob o peso que suporta”.

8 Para Paul Knox (2016), as quatro funções fundamentais de uma cidade são: 1) Capacidade decisória (núcleos de poder político e econômico); 2) Capacidade transformativa (tamanho, densidade e variedade das populações - diversidade de estilos de vida e comportamentos); 3) Função mobilizadora (infraestrutura física); e 4) Função generativa (interação, competitividade, inovação, troca de conhecimento e informações). Já os 13 tipos de cidades foram classificados mediante o enquadramento em cinco temas: Origem (da Antiguidade ao Mercantilismo): 1) Funcional; 2) Em rede; 3) Imperial; Industrialização (séculos XIX e XX): 4) Industrial; 5) Racional; Globalização (a partir da segunda metade do século XX): 6) Global; 7) Das celebridades; Megalópole: 8) Megalópole; 9) Instantânea; 10) Transnacional; 11) Criativa; Sustentabilidade: 12) Verde; 13) Inteligente.

9 Para maiores detalhes, acessar: <http://lhs.unb.br/atlas>.

10 Para Didi-Huberman (2010), Aby Warburg “[...] é para a História da Arte o equivalente ao que Freud, seu contemporâneo, foi para a Psicologia: incorporou questões radicalmente novas para a compreensão da arte, e em particular da memória inconsciente. Mnemosyne foi sua paradoxal obra-prima e seu testamento metodológico [...]”.

11 Como exemplo de atlas revolucionários, Didi-Huberman aponta: Handatlas dadaísta; Album, de Hannah Höch; Arbeitscollagen, de Karl Blossfeldt; Boîteen-valise, de Marcel Duchamp; Atlas, de Marcel Broodthaers e Gerhard Richter; Inventaires, de Christian Boltanski; Montagens fotográficas, de Sol LeWitt; e Album, de Hans-Peter Feldmann.

12 Os fatos estarão dispostos no Atlas, caberá estabelecer na Cronologia as possíveis tramas. Tramas sem a sequência cronológica predeterminada e entendida como uma "uma mistura muito humana e muito pouco 'científica' de causas materiais, de fins e de acasos; de uma fatia da vida que o historiador isola segundo sua conveniência, em que os fatos têm seus laços objetivos e sua importância relativa [...]”. (VEYNE, 2014, p. 42) 


\section{REFERẼNCI IS}

BORGES, J. L. Atlas. Tradução de Heloisa Jahn. São Paulo: Companhia das Letras, 2010.

CALVINO, I. Le città invisibili. Torino: Giulio Einaudi, 1972.

CASTRO, C. de M. Memórias de um orientador de tese. In: NUNES, E. de O. (Org.). A aventura sociológica: objetividade, paixão, improviso e método na pesquisa social. Rio de Janeiro: Zahar, 1978. p. 307-326.

DIDI-HUBERMAN, G. Atlas ou a Gaia ciência inquieta: o olho da história, 3. Tradução de Renata Correio Botelho e Rui Pires Cabral. Lisboa: KKYM/EAUM, 2013.

DIDI-HUBERMAN, G. Atlas. ¿Cómo llevar el mundo as cuestas? 2010. Disponível em: <http://www.museoreinasofia.es/publicaciones/atlascomo-llevar-mundo-cuestas $>$. Acesso em: $11 \mathrm{dez} .2016$.

ELBOROUGH, T; HORSFIELD, A. Atlas of improbable places: a journey to the world's most unusual corners. London: Aurum Press, 2016.

GIL, T. L.; BARLETA, L. B (Coord.). Atlas histórico da América Lusa. Porto Alegre: Ladeira Livros, 2016.

JOHNSON, C. D. Memory, Metaphor, and Aby Warburg's Atlas of Images. Ithaca: Cornell University Press, 2012.

KNOX, P. (Org.). Atlas das cidades. São Paulo: Ed. SENAC, 2016.

MITCHELL, D. Atlas de nuvens. São Paulo: Companhia das Letras, 2016.

MONBEIG, P. Pioneiros e fazendeiros de São Paulo. São Paulo: Hucitec, 1984.

MORINI, M. Atlante di Storia dell'Urbanistica: dalla preistoria all'inizio del secolo XX. Milano: Editore Ulrico Hoepli, 1963.

MUSEU NACIONAL CENTRO DE ARTE REINA SOFÍA. ATLAS. Entrevista con Georges Didi-Huberman. [S.1.], 21 dez. 2010. Disponível em: $\langle$ https://www.youtube.com/watch?v=WwVMni3b2Zo>. Acesso em: 11 68 dez. 2016. 
NEW ENCYCLOPÆDIA BRITANNICA. $15^{\text {th }}$. Chicago: Encyclopædia Britannica Inc., 1985. v. 1.

PANERAI, P. et al. Les Bastides, d'Aquitaine, du Bas-Languedoc et du Béaru: Essai sur la regularité. Bruxelas: Archives d'architecture moderne, 1985.

PEREIRA, M. da S. O rumor das narrativas: a história da arquitetura e do urbanismo do século XX no Brasil como problema historiográfico - notas para uma avaliação. Redobra, Salvador, n. 13, ano 5, p. 201-247, 2014.

REIS, N. G. Imagens de vilas e cidades do Brasil Colonial. São Paulo: EDUSP, 2000.

SOLNIT, R.; JELLY-SCHAPIRO, J. (Ed.). Nonstop Metropolis: a New York City Atlas. Oakland: University of California Press, 2016.

TOCQUEVILLE, A. de. Atlas of lost cities: a travel guide to Abandoned and Forsaken Destinations. New York: Black Dog \& Leventhal Publishers, 2016.

TREVISAN, R. Incorporação do ideário da Garden-City inglesa na urbanística moderna brasileira: águas de São Pedro. 2003. Dissertação (Mestrado em Engenharia Urbana) - Universidade Federal de São Carlos, São Carlos, 2003.

TREVISAN, R. Cidades novas. 2009. Tese (Doutorado em Arquitetura e Urbanismo) - Faculdade de Arquitetura e Urbanismo, Universidade de Brasília, Brasília, DF, 2009.

VEYNE, P. Como se escreve a história: Foucault revoluciona a história. Brasília, DF: EdUnB, 2014. 